\title{
PRRC1 wt Allele
}

National Cancer Institute

\section{Source}

National Cancer Institute. PRRC1 wt Allele. NCI Thesaurus. Code C126636.

Human PRRC1 wild-type allele is located in the vicinity of 5q23.2 and is approximately 37 $\mathrm{kb}$ in length. This allele, which encodes protein PRRC1, has no known function. Mutation or deletion of the gene may be associated with leukemogenesis. 